\title{
Review and Analysis: Successful Use of Soil Tunnels in Medieval and Modern Warfare and Smuggling
}

\author{
Kenneth R. Olson' ${ }^{\circledR}$, David R. Speidel ${ }^{2,3,4}$ \\ ${ }^{1}$ Department of Natural Resources, College of Agricultural, Consumer, and Environmental Sciences, University of Illinois, \\ Urbana, USA \\ ${ }^{2}$ US Army Iraq, Mosul and Balad, Iraq \\ ${ }^{3}$ Foreign Agricultural Service, Baqubah and Mahmudiyah, Iraq \\ ${ }^{4}$ Foreign Agricultural Service, Washington DC, USA \\ Email: krolson@illinois.edu
}

How to cite this paper: Olson, K.R. and Speidel, D.R. (2020) Review and Analysis: Successful Use of Soil Tunnels in Medieval and Modern Warfare and Smuggling. Open Journal of Soil Science, 10, 194-215. https://doi.org/10.4236/ojss.2020.105010

Received: April 19, 2020

Accepted: May 15, 2020

Published: May 18, 2020

Copyright $\odot 2020$ by author(s) and Scientific Research Publishing Inc. This work is licensed under the Creative Commons Attribution International License (CC BY 4.0).

http://creativecommons.org/licenses/by/4.0/

\section{(c) (i) Open Access}

\begin{abstract}
For more than 2500 years, soil tunnels have been used in warfare and smuggling. Initially tunnels were utilized to attack fortresses that were underlain by unconsolidated (non-bedrock) soil materials. Later tunnels provided housing and served as smuggling corridors. The medieval warfare undermining technique involved digging soil tunnels with wooden or beam props to hold up the soil ceilings. Then flammable material, such as hay or straw, was put in the tunnel and set on fire. The fire burnt the support beams which collapsed the soil tunnel ceilings and undermined the overlying perimeter wall. Later gunpowder and dynamite replaced fire when attempting to collapse a tunnel, fortress or perimeter defense. Modern warfare soil tunnels were the pathways used to move troops, weapons and supplies to the other side of a border or wall for surprise attacks. Most of the soil tunnels were placed in easy-to-dig unconsolidated soil materials that had a low water table and were not subject to flooding. Eventually, machinery was used to drill through bedrock permitting deeper and longer tunnels for troop movement or smuggling. However, when drilling through bedrock under international borders, the process creates both noise and vibrations which were often detected by the enemy. Once discovered the tunnels were often collapsed by blowing up the tunnel, injection of gas, filling with water or wastewater, or inserting barriers. A series of case studies will be examined with the goal of determining soil and site criteria required to permit successful tunneling. The most restrictive soil and geologic conditions will be identified as well as potential mitigation methods used to
\end{abstract}


overcome the site restrictions will be documented. Countries with warfare or smuggling issues along their borders, such as Israel and United States, need to identify the sections of the border most likely to be undermined by soil tunnels. In the case of Israel their entire border is susceptible as a result of the favorable arid climate, soils and geology. The US border with Mexico can become vulnerable wherever a new wall is created. Without a wall there is usually no need for soil tunnels. The US Department of Homeland Security and border patrol will need to monitor the noise and vibrations, just like the Israel does, to identify future soil tunnel locations. Eventually most of $3200 \mathrm{~km}$ border will have a wall that will become the target of more soil tunnels for smuggling goods and people from Mexico into the United States.

\section{Keywords}

Soil Tunnels, Tunnel Warfare, Undermining, Smuggling, Fortresses, United States Border Wall, Israel Border, Mexico Border, United States Border, Rio Grande River

\section{Introduction}

Earthen tunnels have been used to cross under country borders, in military conflicts and to smuggle supplies, people, weapons and drugs. Tunneling is a battle military tactic that goes back more than 2500 years. Earthen tunnels have been dug between Lebanon and Israel, Syria and Israel, Gaza and Israel, Egypt and Gaza, North Korea and South Korea, Cambodia and Vietnam and Mexico and the United States to permit the movement of soldiers, supplies, weapons and drugs under the borders. North Korea, Iraq and Iran used tunnels to hide weapons, including nuclear, and other military equipment and supplies. In the early 2000s, ISIS created many earthen tunnels under Iraqi and Syrian cities for military use.

This paper will analyze much more recent examples of the underground manmade soil tunnels that for more than 2500 years have been used in warfare and smuggling. We will examine the efficacy of the tunnels used by insurgents an important tactic to defeat the impact of defoliants on the surface jungle specifically, Agent Orange and Agent Blue, toxic defoliants applied to much of southern Vietnam's vegetation for a decade of war with the United States.

This research paper included a series of medieval and modern case studies from around the world where earthen tunnels were used primarily in warfare and smuggling. The primary objective is to assess the soil and geological materials, climate, bedrock, permanent water table conditions that existed where earthen soil tunnel sites have been created in both medieval and modern times. An attempt will be made to identify which site conditions cannot be easily overcome and need to be avoided. The second objective is to provide a criterion that can be used by countries to identify borders that could be susceptible to soils tunneling. 


\subsection{Medieval Soil Tunnel Warfare}

Tunnel warfare is the name for a war conducted in other underground spaces. It can include the construction of underground facilities used to defend or attack and makes use of any existing natural caves in bedrock (Syria and Iraq) and any undermining in unconsolidated materials for military purposes. Artificial underground facilities can also be used to undermine fortifications or to slip into enemy territory for a surprise attack. Tunnel warfare can strengthen a defense by creating the possibility of a counterattack, ambush, and the ability to move troops around the battlefield unseen and protected. Mining and undermining tactics has been used since antiquity against fortresses, walled cities and fortified military positions. Ancient Greeks and Chinese used undermining and mining during the siege of cities. Romans employed tunnels and trenches for guerrilla-like warfare between $500 \mathrm{BC}$ and $2000 \mathrm{AD}$. The earthen tunnels can shelter both combatants and non-combatants from attack [1].

\subsection{Syrian Tunnels}

The Syrian conflict has moved subterranean warfare to the forefront and provided a physical link to these tactics that go back to ancient times. Most of Syria's modern cities are built on layer after layer of ancient structures. The city of Aleppo, for example, is believed to have been continuously inhabited since the Copper Age, around 6000 BC, and Damascus was an urban center 2000 years before Julius Caesar. British archaeologists concluded in 2009 that remains of 20 Roman soldiers unearthed in a tunnel beneath the town's ramparts had been killed in a clash with the invading Persians seeking to dig their way into the fortress. Persians, in about $256 \mathrm{AD}$, may have been an earliest user of chemical warfare-pumping in a poisonous mix of burning sulfur crystals and bitumen that killed the Romans in minutes. In 2019 the Kurds found three major ISIS soil tunnels and cave complexes on the Turkey border with Syria.

\subsection{Modern Warfare Case Studies}

Fortifications were undermined and collapsed using gunpowder, cordite and dynamite. Eventually fortifications were very expensive to build so they were placed totally underground to protect crews and ammunition. In trench warfare with fortified strongholds, the tactic of digging and undermining the enemy positions was used in the Crimean War, the American Civil War, the Siege of Petersburg, the Russo-Japanese War and the Siege of Port Arthur. Extensive undermining warfare was utilized by the German, French, British and Australian troops on the Western Front during WWI and WWII where the largely static frontlines favored undermining [2]. On the Eastern Front the Russian troops also used undermining.

Tunnel warfare was used as guerrilla tactics in 1937 to 1945 by the Chinese in the Second Sino-Japanese War. The tunnel systems were easy to construct and enabled small forces to successfully fight superior enemies. However, in the 
1960s and 1970s, the Vietnamese did use tunnels for housing and military headquarters during the Vietnam War. In the late 1960s the soil tunnels were repurposed and used during warfare and to permit migration under borders. Caves and caverns within the mountains of Afghanistan and Pakistan were extended by tunnels and used to escape United States military bombing and ground forces by providing escape routes.

During the Korean War, North Korea prepared several transport tunnels to carry 10,000 troops per hour for a possible invasion of South Korea. The tunnels were eventually detected, and a barrier was constructed under the demilitarized zone. The South Korean sections of the tunnels were converted into a tourist stop.

\subsection{China Soil Tunnels}

In $1500 \mathrm{AD}$ soil tunnels were used as below ground living space in China. Millions of Chinese were living in caves and tunnel systems in China. Most of these sites were well-drained with a low water table. Tunnels and caves dug in loess (windblown silt) soils (Mollisols formed under grass) were easy to dig by hand but they lacked enough cementation that would have made soil more stable. During the 16th century one of the deadliest sequences of earthquakes collapsed these soil tunnels, killing more than 830,000 Chinese people. Consequently, the use of soil tunnels for housing was abandoned [3].

\subsection{Cambodia and Vietnam Border}

The military use of soil tunnel networks under the jungle terrain of South Vietnam started during WWII (1936 to early 1945) when Viet Minh national guerillas fought the Japanese in the late 1940s, 1950s and early 1960s during their war of independence from French colonial authority. Tunnels were often dug by hand, in Oxisols and Ultisols soils (Figure 1) of the Old Alluvium terraces (Figure 2, the orange color) only a short distance at a time. The Old Alluvium terrace [4] was the only landform in South Vietnam which could be utilized for soil tunnels since the soils were deeply weathered and had a low water table. During the Vietnam War in the 1960s the United States increasingly escalated its military presence in Vietnam in support of a non-Communist regime in South Vietnam. The National Front for Liberation of South Vietnam (NLF) and the People's Liberation Armed Forces (PLAF) were Communist supporters in South Vietnam and they gradually expanded the soil tunnels in South Vietnam.

At its peak, during the Vietnam War, the network of tunnels in the Iron Triangle and $\mathrm{Cu}$ Chi district linked PLAF support bases over a distance of some 250 $\mathrm{km}$, from the Ho Chi Minh trail and Cambodian border to the outskirts Saigon (Ho Chi Minh City) [3]. The Old Alluvium terrace was not the only Vietnam landscape (Figure 2) utilized for soil tunnels. There were soil tunnels near the Vietnam DMZ ( $17^{\text {th }}$ parallel) and some remain for tourists to visit. The $\mathrm{Cu} \mathrm{Chi}$ and Iron Triangle soil tunnels (Figure 2) are located on the old Alluvial terrace [4]. As the United States relied heavily on aerial bombing, The People's Army of 


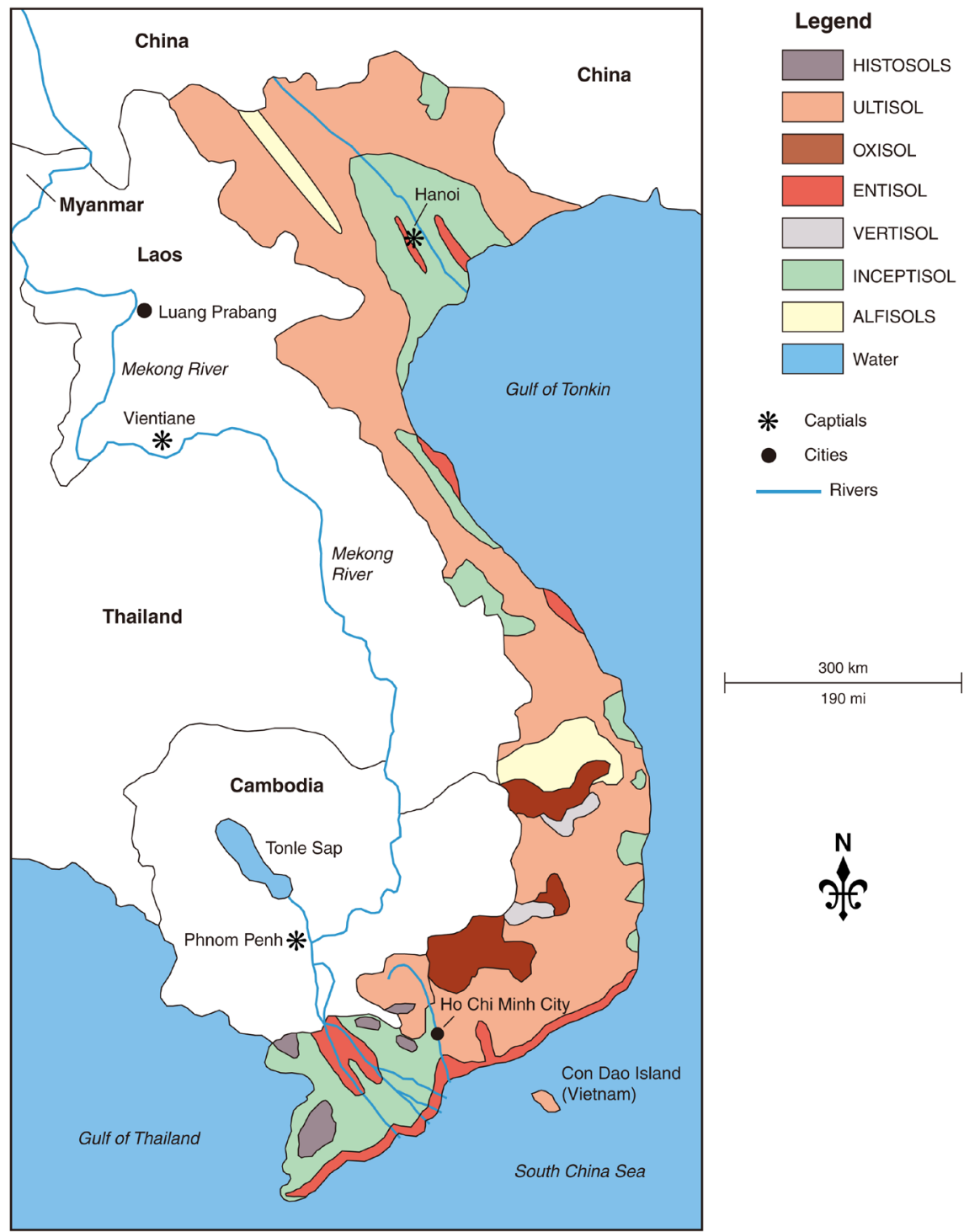

Figure 1. A soil map of Vietnam (Olson and Morton 2017). Adapted from FAO/ UNESCO Preliminary Definitions, Legend and Correlation Table of the Soil Map of the World. World Soil Resources Report no. 12; Rome 1964. Reprinted with permission from Open Journal of Soil Science 2017, 7:34-51. Map by Mic Greenberg.

Vietnam (PAVN) and PLAF went underground in order to survive and continue their guerrilla tactics against the much better-supplied enemy. In heavily bombed areas, people spent much of their life underground, and the $\mathrm{Cu} C h i$ tunnels grew to house entire underground villages, in effect, with living quarters, kitchens, ordnance factories, hospitals and bomb shelters (Figure 3). In some areas there were even large theaters and music halls to provide diversion for the troops (many of them peasants) and their supporters. The tunnels proved very effective in hiding and protecting the PLAF in the 1960s during US bombing of the area. The nature and properties of the Old Alluvium soils (Ultisols and Oxisols) (Figure 1) was the key to the soil tunnels being so resilient [3]. The soil tunnels were dug without the need for reinforcement of the ceiling. 


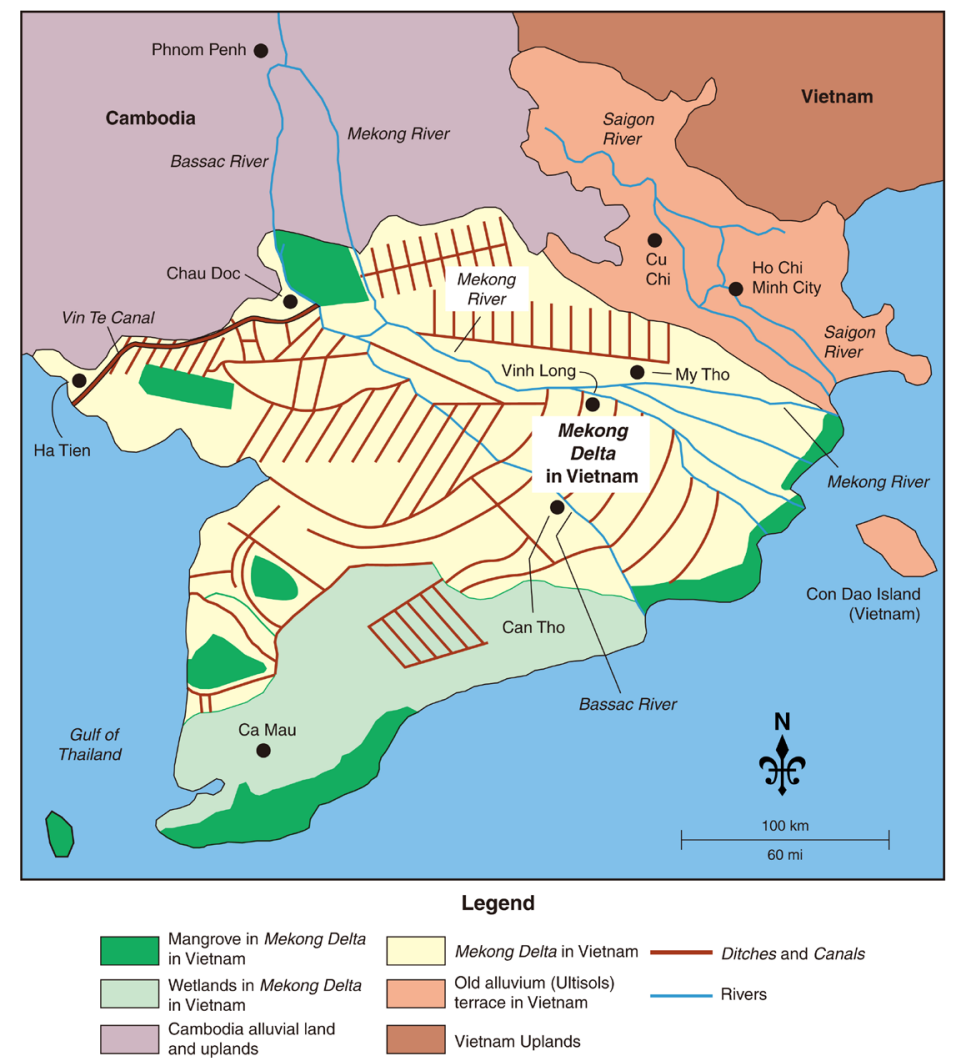

Figure 2. The Mekong River Delta region has an extensive system of canals, ditches, dikes and polders (built by the French in 1800s) that was expanded for Vietnam troop movement and post-1970s by Vietnamese farmers to intensify agricultural cropping systems. Reprinted with permission from Journal of Soil and Water Conservation 2018, 73: 83A89A.

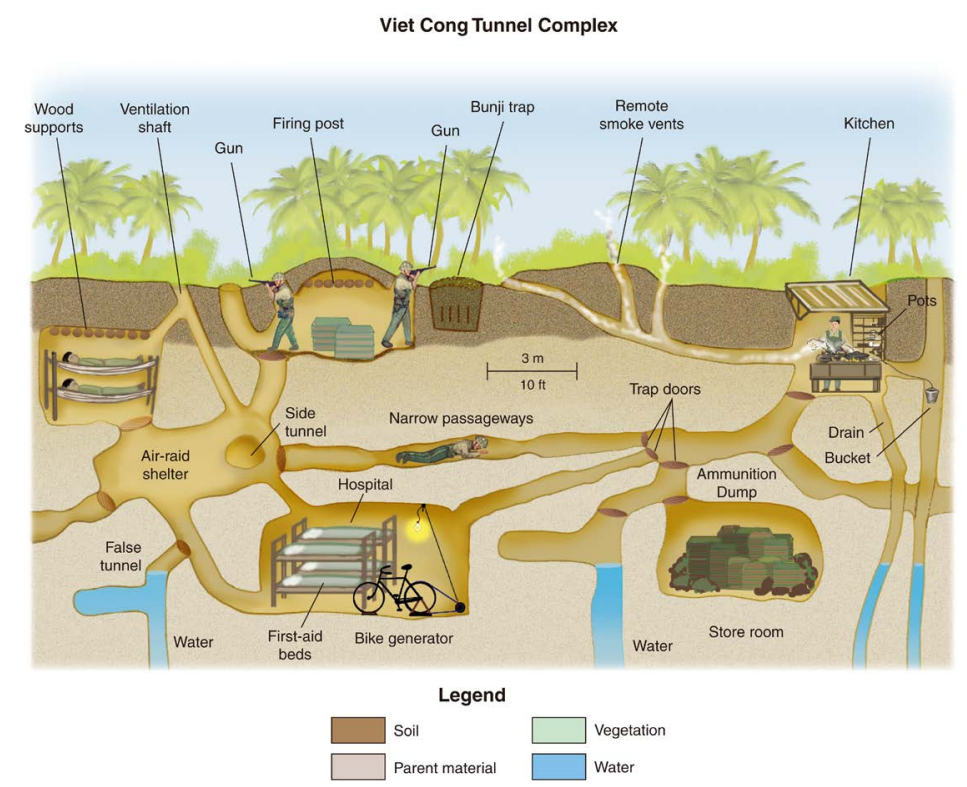

Figure 3. This diagram illustrates a multi-level People's Liberation Armed Forces soil tunnel complex used for living quarters and fighting. Reprinted with permission from Open Journal of Soil Science 2017, 7: 34-51. 
The Old Alluvium terrace soils are well drained. Even during the monsoon season in a tropical climate, the parent material is old unconsolidated alluvium with few rock fragments except for the laterite (Fe) masses just above the permanent water table which is often 5 to $10 \mathrm{~m}$ below the soil surface. The low water table and hand-dug tunnels provided an aerated space below the surface soil and resulted in the Fe binding or cementing the soil particles together and eliminated the need for beams to hold up the ceilings.

\subsection{North and South Korea Demilitarized Zone}

The tunnels are hundred meters below the earth's surface and stretch from the North Korean side of the heavily fortified Demilitarized Zone (Figure 4) into neighboring South Korea and were built in the 1950s and 1970s. One tunnel was discovered just $50 \mathrm{~km}$ (31 mi) from the South's capital, Seoul. South Korea says the four passages, the so-called Tunnels of Aggression (Figure 5), were built to move thousands of North Korean troops quickly and covertly underneath the Demilitarized Zone and onto South Korean soil for an invasion (Figure 6, map). But in the decades since their discovery, some of the tunnels on the South Korea side and under the DMZ have found new life as a tourist destination. Thousands of Koreans and foreign visitors explore these odd relics of an inactive conflict. While tourists can see the North Korean handiwork, what they cannot do is cross under the DMZ border, as the passage to North Korea is now blocked by concrete slabs.

The Korean demilitarized zone Entisols and Alfisols soils are shallow and underlain by bedrock (Figure 6). The soil has a low water table. The vegetation includes many endangered plant species as a result of becoming a no-man's land. More than six decades as a no-man's land has allowed some endangered species of plants and wildlife to thrive in the Demilitarized Zone. South Korea's tourism authority says it has "unintentionally become a haven for wildlife."

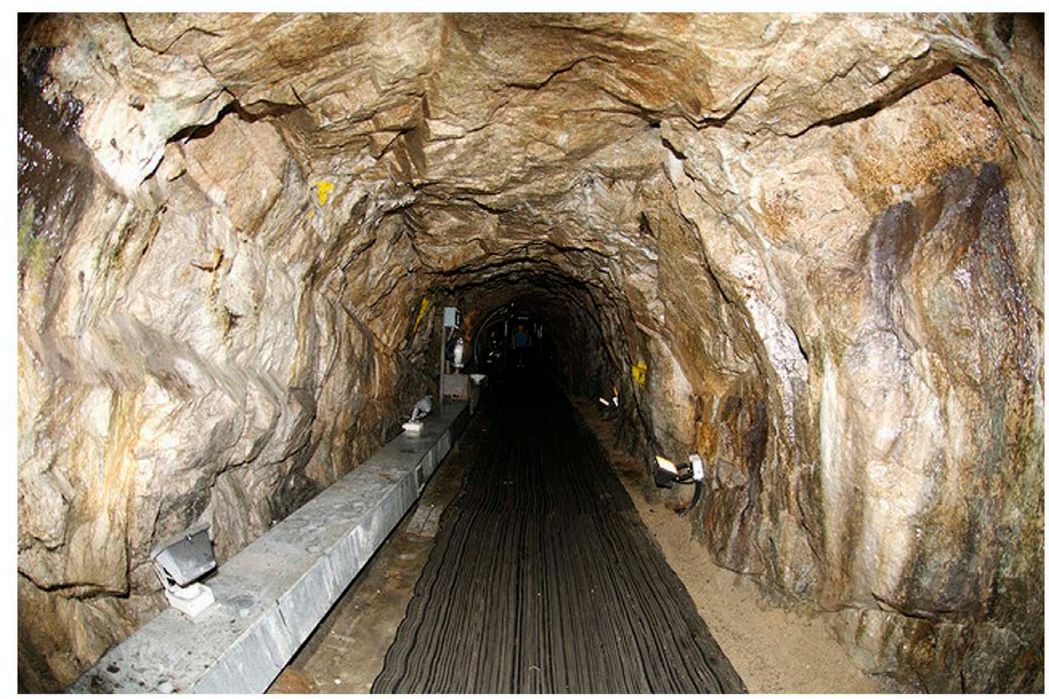

Figure 4. The bedrock tunnels under the DMZ in Korea. 


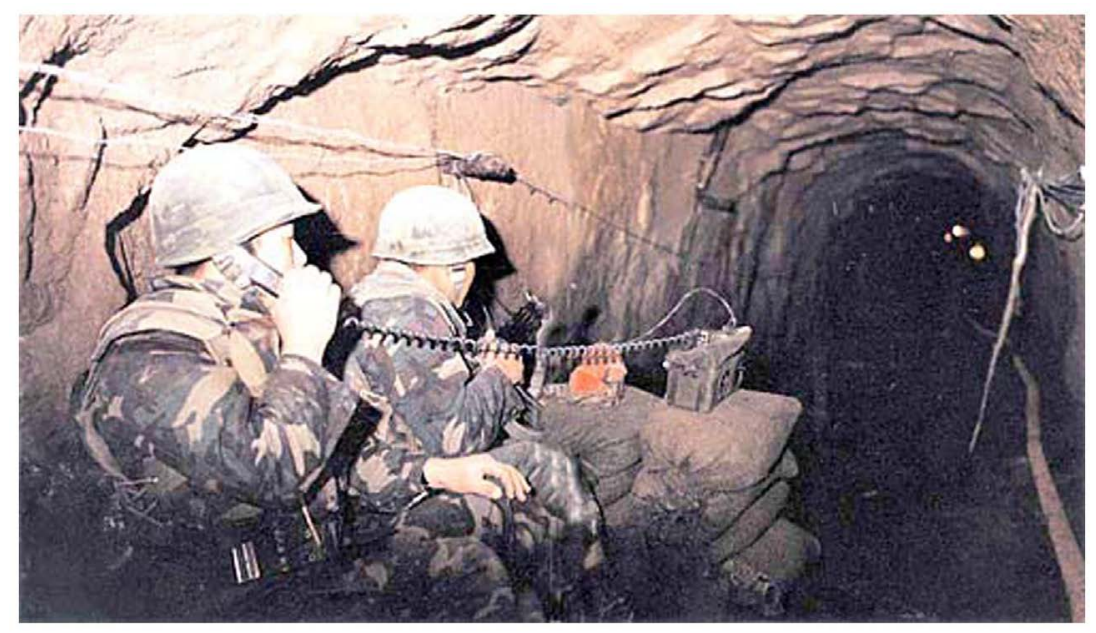

Figure 5. Korean DMZ tunnel used to train US Military.

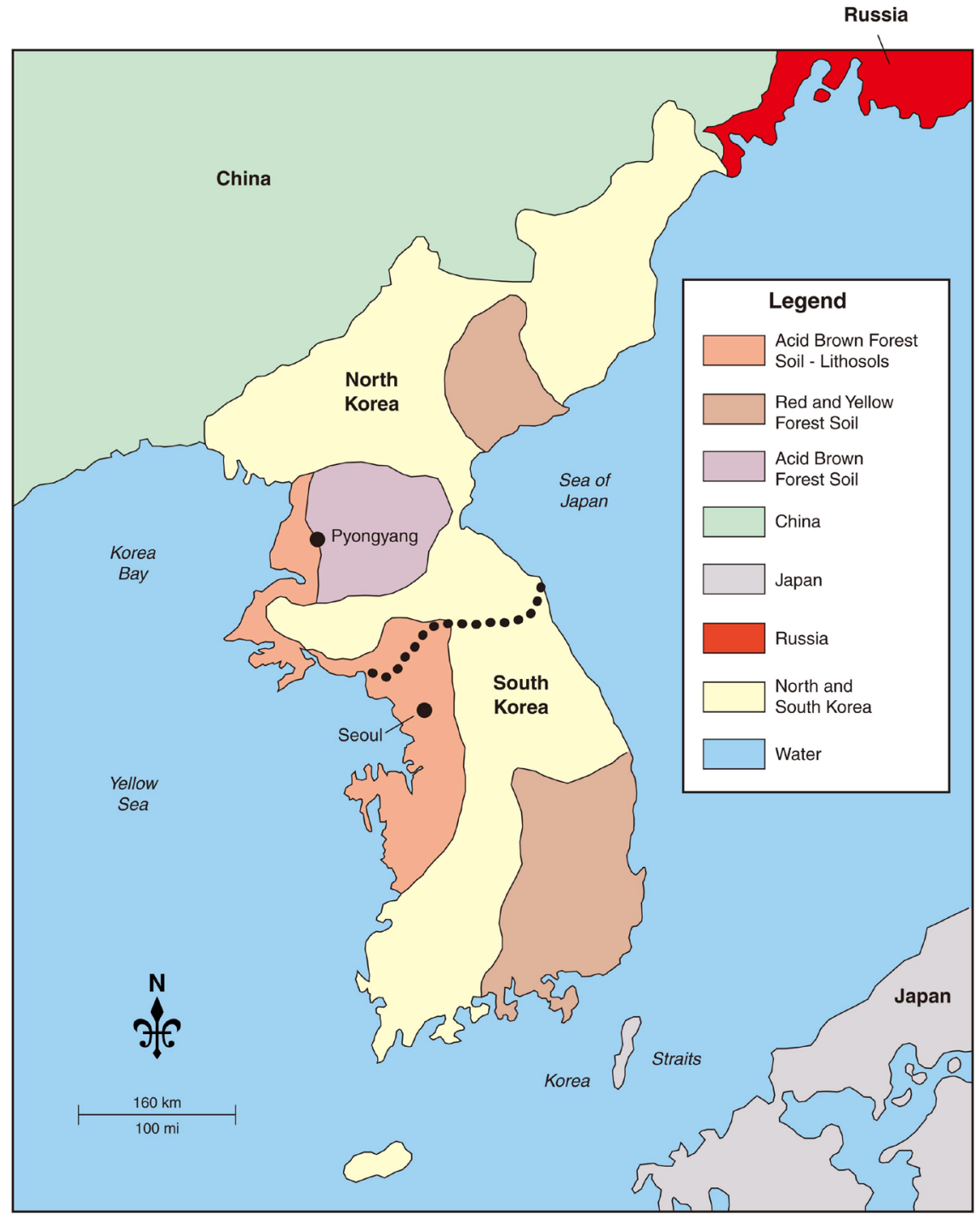

Figure 6. Soils and Korea Peninsula. The location of the DMZ with soil tunnels is shown beneath. 


\subsection{Iran Tunnels}

Since 1935 Iran has used dynamite to create tunnel openings for roadways. These include the Kandovan tunnel and the Tehran-Northern Expressway with a total of 137 tunnels and have a length of $45 \mathrm{~km}$ in both directions and the Khoramabad-Pol-e-Zal Expressway with $25 \mathrm{~km}$ of twin tunnels that were excavated by the drill-and-blast method. This technology was then used to create earthen tunnels for other purposes including military.

The New York Times [5] reported that Iran had hidden much of its nuclear infrastructure in tunnels and bunkers across the country over the past decade. By doing so Iran had protected its nuclear infrastructure from attack and had also obscured the scale and nature of its atomic program. There were thousands of big drill and blast tunnels in extensive mountainous Iran, but that the purpose of the tunnels was not clear. Iran later acknowledged it is developing uranium enrichment facilities at several sites, including Isfahan and Natanz. But Iran claimed its nuclear activities were for peaceful purposes-mainly to generate electricity. President Barack Obama and other Western leaders accused Iran of building a secret nuclear plant inside a mountain near the city of Qum, south of Tehran. Iran later admitted developing the facility. Iranian President Mahmoud Ahmadinejad had long played a prominent role in developing Iran's tunnel infrastructure, first as an engineer and founder of Iran's Tunneling Association, and in 2010 as President. These soil (Ultisols and Aridisols) tunnels were constructed by engineers in an arid climate with a lower permanent water table. The unconsolidated parent material overlies bedrock which can be excavated with power drills.

\subsection{Iraq Tunnels}

Under the Iraqi town of Sinjar, Islamic State (ISIS) of Iraq and Syria militants built a network of tunnels, complete with sleeping quarters, wired with electricity and fortified with sandbags [6]. The tunnels, which were uncovered by Kurdish forces that took the city in northwestern Iraq after more than a year of ISIS rule. Between 30 and 40 tunnels inside Sinjar were found by the Iraqi Kurdish fighters known as Peshmerga. It was a soil tunnel network inside the city.

Daesh (the Arabic acronym for ISIS) dug these trenches in order to hide from airstrikes and had free movement underground as well as to store weapons and explosives. Two soil tunnels ran several hundred meters, each starting and ending from houses, through holes knocked in walls or floors. This was their military arsenal. The narrow tunnels, carved in the rock apparently with jackhammers or other handheld equipment, are just tall enough for a man to stand in. Rows of sandbags line sections of the walls, electrical wires power fans and lights and metal braces reinforce the ceilings. One section of the tunnel resembled a bunker [6].

In 2017 a brave Kurdistan team explored the aftermath of the east Mosul military operation where Peshmerga discovered several ISIS underground tunnels. In the documentary, the Kurdistan news team led by Ragaz Rasheed visited the 
retaken villages and showed the aftermath of war while interviewing some Peshmerga officers on the front lines. The team showed several ISIS tunnels discovered by Peshmerga. The passageways differed from each other in terms of depth and length. In one of the tunnels, Peshmerga found some ISIS extremists still alive. The documentary had been filmed a few months after Peshmerga liberated the area on August 14, 2017, from the jihadist group. These soil tunnels could be constructed in an arid climate with soils (Aridisols) having a lower permanent water table. The parent material is unconsolidated and overlies bedrock which can be excavated with power drills.

ISIS has built extensive networks under cities it had conquered to evade roundthe-clock air strikes by the United States and its allies and used tunnels to pump oil from captured fields, a key source of funding. Approximately 30 or 40 tunnels were found inside Sinjar, an Iraqi town captured by the jihadists in 2014 and retaken in November 2015 by the Kurdish.

\subsection{Syria and Israel}

Fighters of the Islamic Front rebel group blasted the large Syrian Army base at Wadi al-Deif in Idlib province in March 2014 from an unexpected quarter. They detonated an estimated $60 \mathrm{mt}$ of explosives stacked at the end of an 850-m tunnel they had spent weeks digging. The huge explosion, which killed dozens of Syrian officers and blew an entire hillside hundreds of meters into the air. While barbaric it did demonstrate a successful use of tunnels as a military tactic.

Across the Middle East, it seems that everyone is going underground again, including Hezbollah, Hamas, and ISIS. Iran has constructed extensive nuclear facilities in underground bunkers and inside mountains to protect them from Israeli or US air strikes. Even the Syrian regime is tunneling. The Jaysh al-Islam coalition released a documentary that revealed a self-contained underground complex constructed in the bowels of Damascus under the Harasta quarter for Syrian President Bashar Assad and his inner circle. It included an intelligence center and chemical decontamination chambers. According to the Pentagon's Joint Improvised-Threat Defeat Organization, there have been more than 50 major tunnel bombings occurring in Syria and Iraq as insurgent groups resorted to a primitive combat strategy to counter the technological superiority of the state military forces.

Some of the bombings have been pulverizing powerful. The March 4, 2015, tunnel bombing of the Syrian Air Force headquarters in Aleppo was so strong that it was registered as a 2.3-magnitude earthquake by the European-Mediterranean Seismological Center west of the city. There had never been such an intense network of tunnels as there is in Syria. It started in Homs in 2012. Military analysts estimate that the Syrian rebel groups have dug between 500 and 1000 tunnel systems.

\subsection{Israel and Gaza Border}

During the 2014 Israel-Gaza conflict, Israel launched a ground offensive into 
Gaza (Figure 7) with the primary goal being to fully destroy the cross-border tunnels. In total 31 tunnels were found and destroyed during the weeks the Israel Defense Forces (IDF) were in Gaza. On August 11, 2014, the IDF announced they had successfully tested a system that could be used to detect these tunnels. This new system apparently uses a combination of sensors and special transmitters to locate underground tunnels. The IDF expected development at a cost of $\$ 0.5$ billion US and was deployed by 2015 .

In 2105 Israel destroyed an earthen tunnel dug by Hamas from Gaza into Israeli territory, dealing a substantial blow to one of the main strategic assets in the Islamic militant group's arsenal. It was the second cross-border tunnel in six weeks that the Israeli military said it had detected soil tunnels using new technologies and then destroyed them. Israeli officials have predicted the end of the cross-border threat from such tunnels. The decision was made to incapacitate the tunnel despite the current tensions over Jerusalem [7]. During the 2014 Gaza war, several Israeli soldiers were ambushed and killed by militants who emerged from underground tunnels. The Israeli authorities claim the tunnels violate Israeli sovereignty and threaten civilians living in the border area.

The latest tunnels to be destroyed extended hundreds of meters into Israeli territory, according to the military, and ended in open farmland about two kilometers from the nearest Israeli village [8]. Israel had invested heavily in trying to thwart the tunneling. Israel recently went public with its plans for a subterranean barrier has been using virtual-reality systems to simulate fighting in tunnels and is training troops in mock-ups of maze-like underground networks. Historically, Israel destroyed the earthen tunnels by bombing them. Up to a dozen Islamic Jihad militants were killed in the tunnel's collapse and two Hamas militants were rescued.

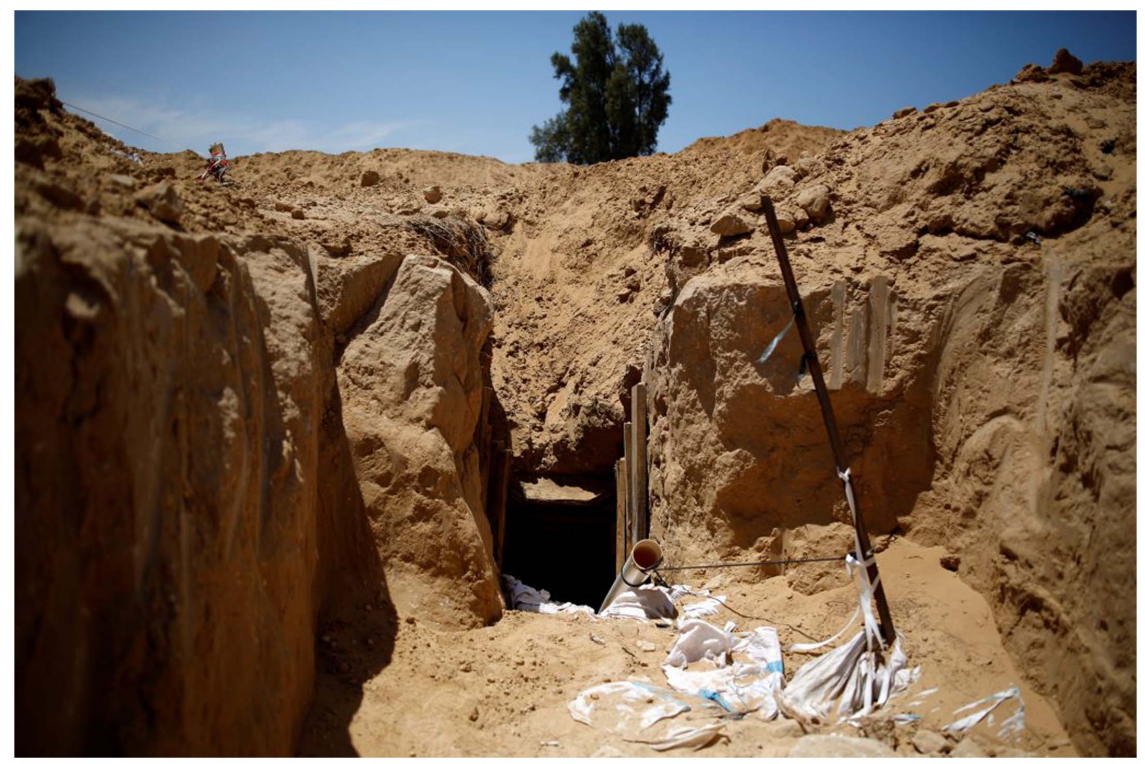

Figure 7. Entrance to a soil tunnel dug by the Palestinians under the Syria and Israel border. 
In Gaza, Hamas has been confounding the Israelis for years with an elaborate labyrinth of tunnels for infiltrating fighters into the Jewish state, launching rockets or sheltering commanders during combat. This has triggered three controversial invasions of the densely populated coastal strip. In Operation Protective Edge, the incursion in summer 2014, Israel destroyed 32 Hamas tunnels, but Palestinian sources said Hamas has more than 1000 people working underground building a new network. The tunnels were dug into deep soils (Alfisols, Inceptisols and Aridisols) underlain by unconsolidated parent material having a low water table. The border area is in an arid climate. There are few rocks and little bedrock below the soil surface.

\subsection{Gaza and Egypt}

The Gaza Strip smuggling tunnels are passages that have been created under the Philadelphi Corridor a narrow strip of land, $14 \mathrm{~km}$ in length, situated along the border between the Gaza Strip and Egypt (Figure 8, map). After the Egypt-Israel Peace Treaty of 1979, the town of Rahahin on the southern Gaza Strip was split by this Corridor. One part is in the southern part of Gaza, and the smaller part of the town is in Egypt.

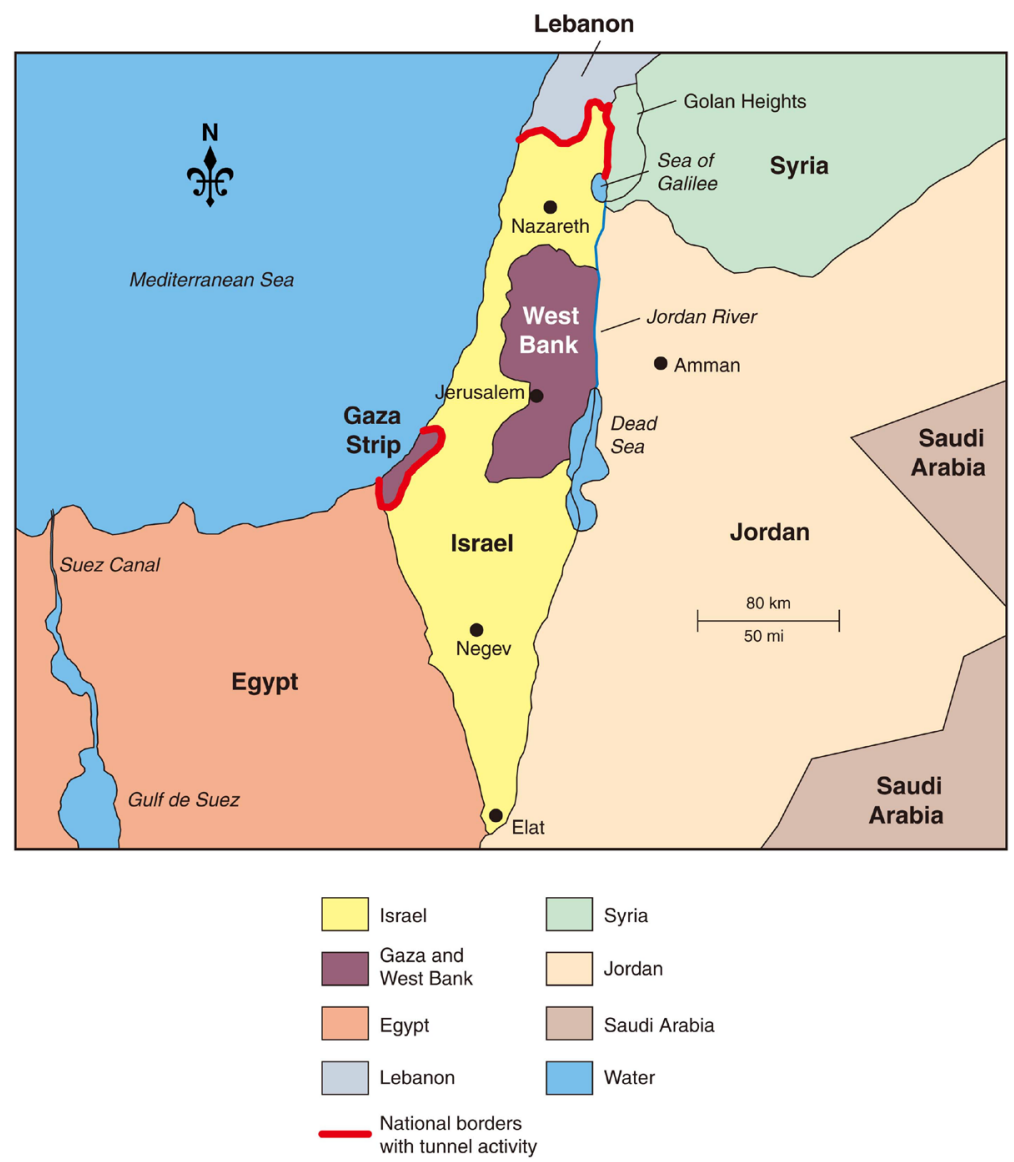

Figure 8. Middle East map showing the location of the tunnels between Egypt and Gaza Strip, Gaza Strip and Israel, Lebanon and Israel and Syria and Israel. Map by Mic Greenberg. 
The first recorded discovery of a tunnel by Israel was in 1983, after Israel had withdrawn from the Sinai [9]. The border, redrawn in 1982 after the Egypt-Israel Peace Treaty divided Rafah into an Egyptian and a Gazan part. The tunnels used to start from the basements of houses in Rafah on one side of the border and end in houses in Rafah on the other side (Matza 2004). After Israel withdrew from Gaza in 2005, the Philadelphi Corridor was placed under the control of the Palestine Authority until 2007. When Hamas seized power in 2007, Egypt and Israel closed borders with Gaza [10].

In 2009, Egypt began the construction of an underground barrier to block existing tunnels and make new ones harder to dig. In 2013-2014, Egypt's military has destroyed most of the 1200 tunnels which were used to smuggle food, weapons and other goods into Gaza (Matza 2004). The blockage of the Gaza Strip caused a shortage of certain basic products, especially construction materials, fuel, some consumer articles, and medicines and medical supplies. Import restrictions, including of basic building materials, have led to the proliferation of tunnels under the border with Egypt. As Israel limited the Palestinian freedom of movement, for most Gazans the tunnels were the only way to move to and from Gaza.

The tunnels were used to smuggle a wide range of goods, including fuel, gas, cement, construction materials, raw materials, pesticides, seeds, agricultural tools, preservatives, packaging material, spare parts, livestock, zoo animals, food, medicines, clothes, car parts, building supplies, weapons and luxury items in general. Initially, the tunnels were used for moving consumer goods and medicines. During the First Intifada (1987 to 1993), some secret tunnels were utilized by militant groups to bring in arms and money [9].

Smuggling fuel through the tunnels had been the primary source of fuel for Gaza's only power plant. Electricity is needed for the desalination of drinking water. After Egypt demolished hundreds of tunnels in 2013 and Israel closed the Kerem Shalon Crossing, a shortage in fuel caused the shutdown of the power plant. Increased fuel shortages and high prices, due to the intensified anti-tunnels measures by the Egyptian el-Sisi regime, halted the functioning of sewage treatment facilities in Gaza in 2014. Untreated wastewater was pumped into the Mediterranean, causing serious environment pollution and swimming prohibition at the beaches.

According to an article by Nicolas Pelham [9] in the Journal of Palestine Studies (IPS), child labor was employed in the smuggling tunnels with the justification that children were more "nimble." Despite calls from human rights groups, the Gaza government has not completely stopped using child labor. Pelham reported that at least 160 persons, including children, have been killed in the tunnels.

Contractors operating from basements of houses or an olive grove were able to dig under the border at depths of up to $30 \mathrm{~m}$ and reaching up to $800 \mathrm{~m}$ in length. Many tunnels are of generally high quality of engineering and construction-with some including electricity, ventilation, intercoms, and a rail system- 
they are still very dangerous and are prone to cave-ins. The openings to many tunnels are found within buildings in or around Gaza's southernmost city of Rafah [11]. Israel has destroyed hundreds of homes along the Gaza-Egypt border to enlarge the buffer zone, asserting that they were used to hide smugglers' tunnels.

In late 2009 Egypt started construction of a subterranean barrier to curb the use of smuggling tunnels. In 2010, the Mubarak regime sprayed toxic gas into the tunnels, killing four Palestinians. In 2011, Egypt sealed a series of smugglers' tunnels between its border and the Gaza Strip. In 2013, the Egyptian military shut down the smuggling tunnels connecting Sinai and Gaza by flooding them with sewage. On 11 September 2015, the Egyptian Army pumped water from the Mediterranean Sea into the tunnels. Several Palestinian factions condemned the flooding of the border with sea water because it posed a serious threat to environment and ground water. By August 2014, the Egyptian Military destroyed 1659 smuggling tunnels [7]. The border area was in an arid climate with a deep and well-drained soil (Aridisols). The water table was low, and tunnels were dug through unconsolidated and consolidated parent material. These soil tunnels were blocked, blown up, or flooded with water and sewage.

\subsection{Lebanon and Israel}

The Iranian-backed Hezbollah used a pioneering tunnel system in south Lebanon during its 34-day war with Israel in 2006 (Figure 8). It also prepared for another conflict with its old enemy, Israel, by creating an advanced tunnel network on Israel's northern border. This reputedly includes assault tunnels far into the Jewish state, just like Hamas's infiltration tunnels into Israel's southern desert.

The network, much of which appeared to have been carved out of the rock with pneumatic drills, included prayer rooms, sleeping quarters and electrically powered fans to keep the air circulating through the underground system. It was a city under the city. Israel's military has been seeking ways to counter this old-new form of warfare, which has redefined the concept of the front line, but has not come up with a foolproof system. These tunnels could be constructed in an arid climate with a low permanent water table. The parent material is unconsolidated and overlies bedrock which can be excavated with power drills.

Hezbollah built a vast network of advanced tunnels along the Lebanon border with Israel for use in a future war and using them to conceal tens of thousands of rockets aimed at the Jewish state. The group has built a sprawling underground array of tunnels, bunkers and surveillance outposts along the border with Israel, which it manned at peak readiness for battle.

The soil tunnels were highly advanced, with durable concrete, a 24-hour power supply via underground generators, a ventilation system to prevent damaging military equipment and a web of secondary escape shafts in case of attack. The tunnels housed tens of thousands of rockets ready for launch and were wrapped individually in protective materials in order to preserve them. 
Hezbollah was constantly surveying the Israeli border area with electronic equipment as well as observation posts equipped with night-vision technology. Tunnel construction was said to be continuing around the clock, using primitive means rather than advanced machinery in order to avoid detection by Israeli surveillance. Most of the weapons have been transferred to Lebanon through war-torn Syria, coming from Hezbollah's key allies, the Syrian government and Iran [12].

Tunneling in the rocky terrain of the Lebanon-Israel border is much tougher than in the sandy unconsolidated ground along Gaza's border. Geologists suggested tunneling in the rocky terrain of southern Lebanon was not as difficult as it appeared. A cross-border tunnel hundreds of meters long can be dug in six months [12]. The arid climate and low water table allowed soil (Aridisols) tunnel construction. These soil tunnels were blocked and/or blown up.

\subsection{Afghanistan Tunnels and Caves (Osama Bin Laden Soviet US Forces)}

Osama bin Laden escaped the American revenge mission after $9 / 11$ by hiding in earthen tunnels that he built with funds from the Central Intelligence Agency (CIA) who provided funds for Afghan Mujahidin's war against the Soviet invaders. A series of defense tunnels were built in 1986 near the town of Khost in the mountains of Paktika province, a few kilometers from the border with Pakistan. The goal was to store weapons, create an underground field hospital as well as to provide shelter against Russian air attacks.

Bin Laden, son of a wealthy Saudi building tycoon, was one of the first Muslims to rush to Afghanistan soon after the Soviet invasion of December 1979. He brought his engineers and equipment to help with the job. From Peshawar, weapons were transported across the Pakistan-Afghanistan border by smugglers on foot and on the backs of donkeys. The weapon movement was aided by $\mathrm{Pa}$ kistan, Saudi Arabia and the CIA.

The Qaeda military base camp called Zhawar Al-Badr was created in the walls of gorges in Sodyaki Gohar mountains of eastern Afghanistan, a half-mile lattice of caves and connecting tunnels only 4000 meters from the Pakistan border. The Soviet Army captured the Zhawar Al-Badr base camp in 1986 during the Soviet invasion of Afghanistan after 57 days of intense aerial bombardment and handto-hand combat. The Soviet Army then blew up the base camp which was re-built in six months after the Soviet invaders left.

In a mountain range located in the country of Afghanistan and very close to the Pakistan border, the battle of Tora Bora took place 10 weeks after 9/11. Osama bin Laden escaped through the caves and tunnels in part because the US Army took a "light footprint approach" and used a smaller number of US troops. The US military relied on Afghan commanders and fighters and assumed the Pakistan Army would seal off the Pakistan border, which did not happen.

The Afghanistan tunnels dug below the surface soils (Entisols and Aridisols) in the underlying geological parent material and vadose zone are a product of 
ancient history, climate and geology. Afghanistan is a web of thousands of caves, countless miles of tunnels, deeply dug-in bases and heavily fortified bunkers. Osama bin Laden was a trained engineer and had a lot of American money from the CIA via Pakistan and the war against Soviet forces. Most of the tunnels are in the vadose zone overlying bedrock in arid climates with low water tables.

The original purpose of these Afghanistan tunnels was irrigation and not warfare or smuggling. These irrigation tunnels were called Qanat in Iran and Karezes in Afghanistan. During the ten years of war with the Soviet military in 1980s the Afghanistan insurgents did adapt the Qanats for military tunnel use. The information used by the Soviet and Afghanistan allies is limited. The Soviet tactics used to defeat the Mujahidin use of tunnels was documented in 2001 as part of US forces preparation for Afghanistan operations. The US forces had a poor understanding of Qanat's importance to local agriculture (see Qanat definition and diagrams in [13]. In 2010 civilian advisors with the US State Department assisted a Division Headquarters training for deployment to Kandahar. They determined there was a need for better understanding of the Qanat tunnels and shafts as a local irrigation system. This was based on observation of US military forces actions at a Afghanistan Forward Operating Base after observing shafts into Qanats. Rather than trying to understand the utility of the shafts for irrigation maintenance and working with the local leaders to resolve any security issues, the military closed the shafts to achieve security without understanding that the Qanat tunnels and shafts were an essential part of the irrigation system required to grow crops. Traditional Qanat tunnels and shafts were built by a group of skilled laborers called muqannis. The skill has been passed down from father to son and goes back several generations. The muqannis were key figures in the village leadership. US military had missed that ensuring irrigation water, from Karez tunnels for crops, was critical to the livelihoods of the Afghanistan people and their village's survival.

\subsection{Canadian and United States Border}

There has never been the use of soil tunnels in armed conflicts between the United States and Canada. Tunnels were used to smuggle goods in the US dates to the Derby tunnels in Salem, Massachusetts, in response to Thomas Jefferson's new custom duties. In 2005 a group of Canadian drug smugglers constructed a tunnel below the surface soils (Andisols and Mollisols) between Langley, British Columbia and Lynden, Washington.

\subsection{Mexico and US Border}

The 2000-mile border (Figure 9 map) goes from a tropical climate (Aridisols and Entisols) at Brownsville to an arid climate at Tijuana. The soils and unconsolidated material are deep and has a low water table (Figure 10). These soil tunnels (Figure 11) could be constructed in an arid climate (Aridisols and Entisols) with a low permanent water table. While the high water table in Mollisols 


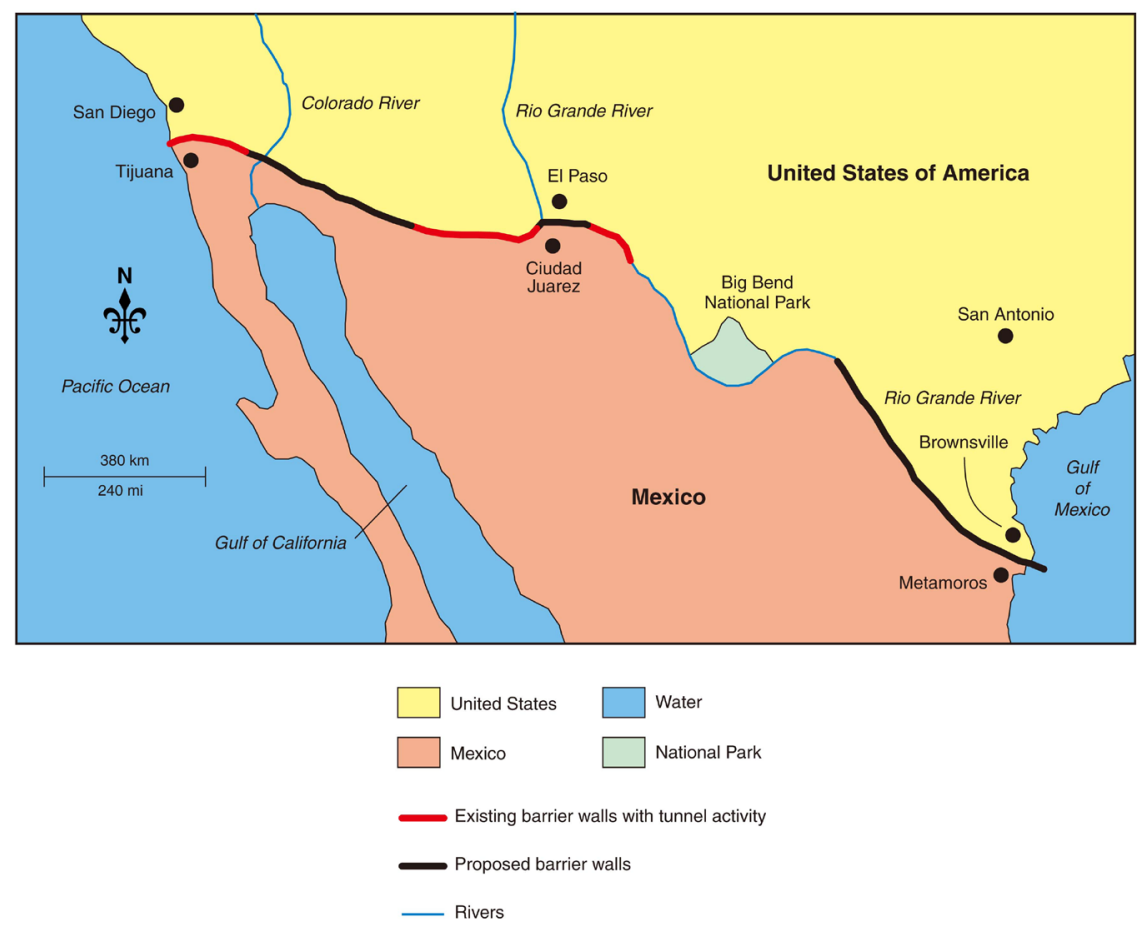

Figure 9. Map of the locations of the existing and proposed barrier walls between Mexico and the United States. Once built, the barrier walls are often undermined by tunnels originating in Mexico. Map by Mic Greenberg.

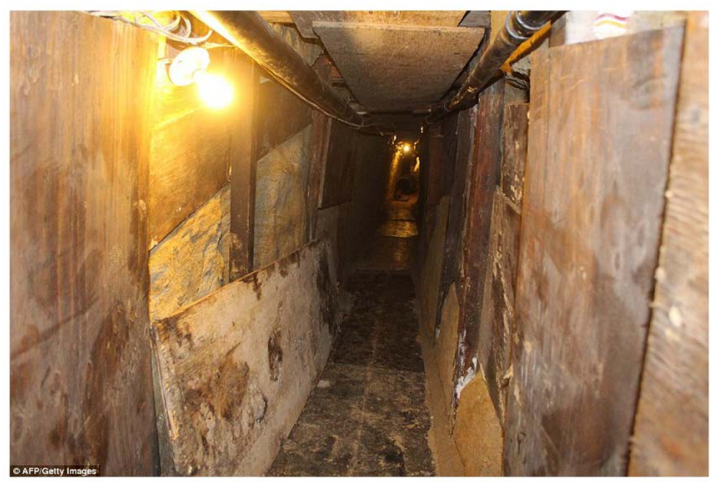

Figure 10. Soil tunnels lined with plywood under the Mexico-United States border.

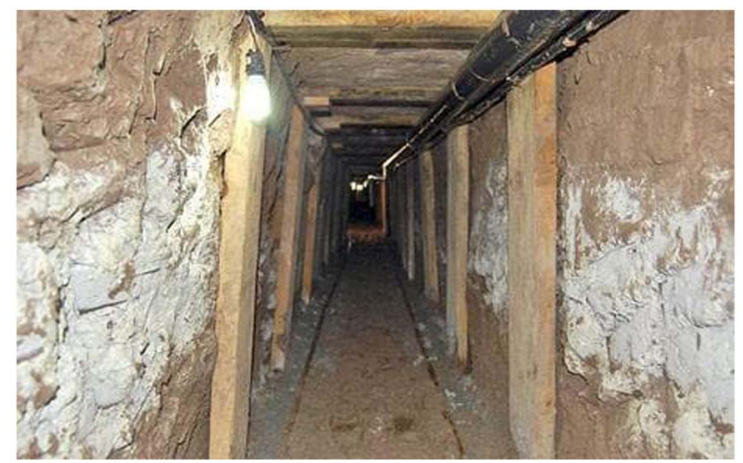

Figure 11. Wood beams holding up the roof of a soil tunnel under the Mexico-United States border. 
and Entisols along the eastern Rio Grande along with potential flooding restricts earthen tunnel construction along the eastern half of the border, conditions are better for tunnel construction in the western half of the border area (Figure 12) which has little potential flooding and a low water table in an arid climate.

Since 1990 over 170 tunnels, often incomplete border tunnels, between the El Paso, United States and Tijuana, Mexico (Pacific Ocean) (Figure 13) have been found. In 2006, a tunnel was found by the US Border task force. The $730 \mathrm{~m}$ long tunnel connected the Tijuana airport to a San Diego warehouse. It was $1.5 \mathrm{~m}$ high and up to $27 \mathrm{~m}$ deep. The floor was cement, the walls were exposed clay and with lighting and ventilation systems. The seeping groundwater was removed by a drainage system. Additional major tunnels were found in 2010, 2012 and 2014 [14].

One of the longest cross-border drugs-smuggling tunnels between Mexico and the US was discovered in 2016 by authorities in San Diego. It was $800 \mathrm{~m}$ long and used to transport an "unprecedented cache" of cocaine and marijuana (Figure 14). It was the 13th sophisticated secret tunnel found along California's border with Mexico since 2006. It was "ingenious" and unlike anything seen before. In the latest incident about $1016 \mathrm{~kg}$ of cocaine and $6350 \mathrm{~kg}$ of marijuana suspected of being transported through the tunnel was seized. This is the largest cocaine seizure ever associated with a tunnel. The tunnel ran from a restaurant in Mexico to a house in California. The latest tunnel ran at a depth of $14 \mathrm{~m}$ from the bottom of an elevator shaft built into a house in Tijuana to a hole in the ground on the American side enclosed within a fenced-in lot set up as a pallet business. The hole was hidden under a trailer-sized rubbish bin that smugglers used to move the drugs from the lot. The tunnel used in the operation was sophisticated with cemented walls and ceilings and a ventilation system and lighting. On the Tijuana side (Figure 14), the tunnel was connected to an elevator that ascended into the house. Seeping drainage water was periodically removed from the tunnels and was not part of a permanent water table.

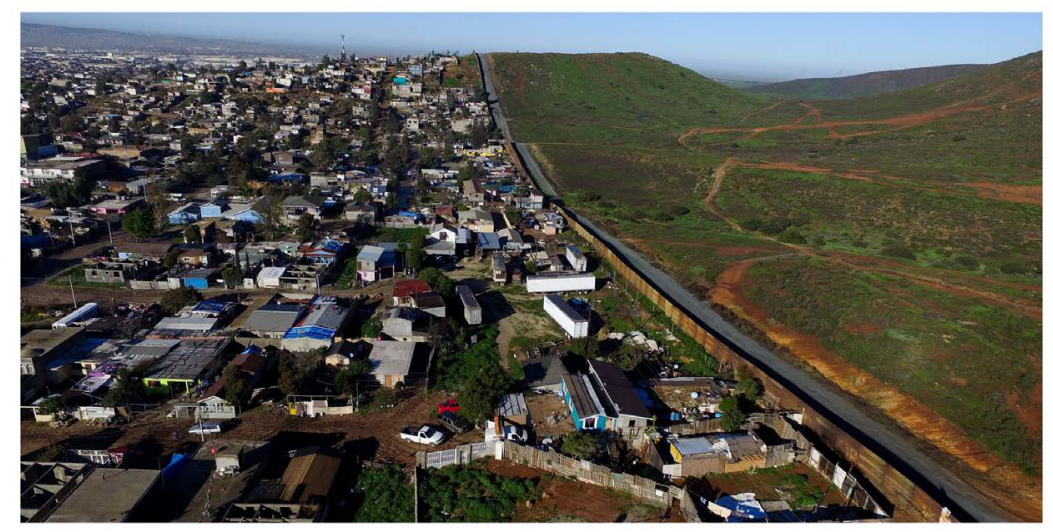

Figure 12. The Mexico-United States rolling landscape. The border wall separates the two countries and the paved road along the border wall is on the United States side and the housing in on the Mexico side. 


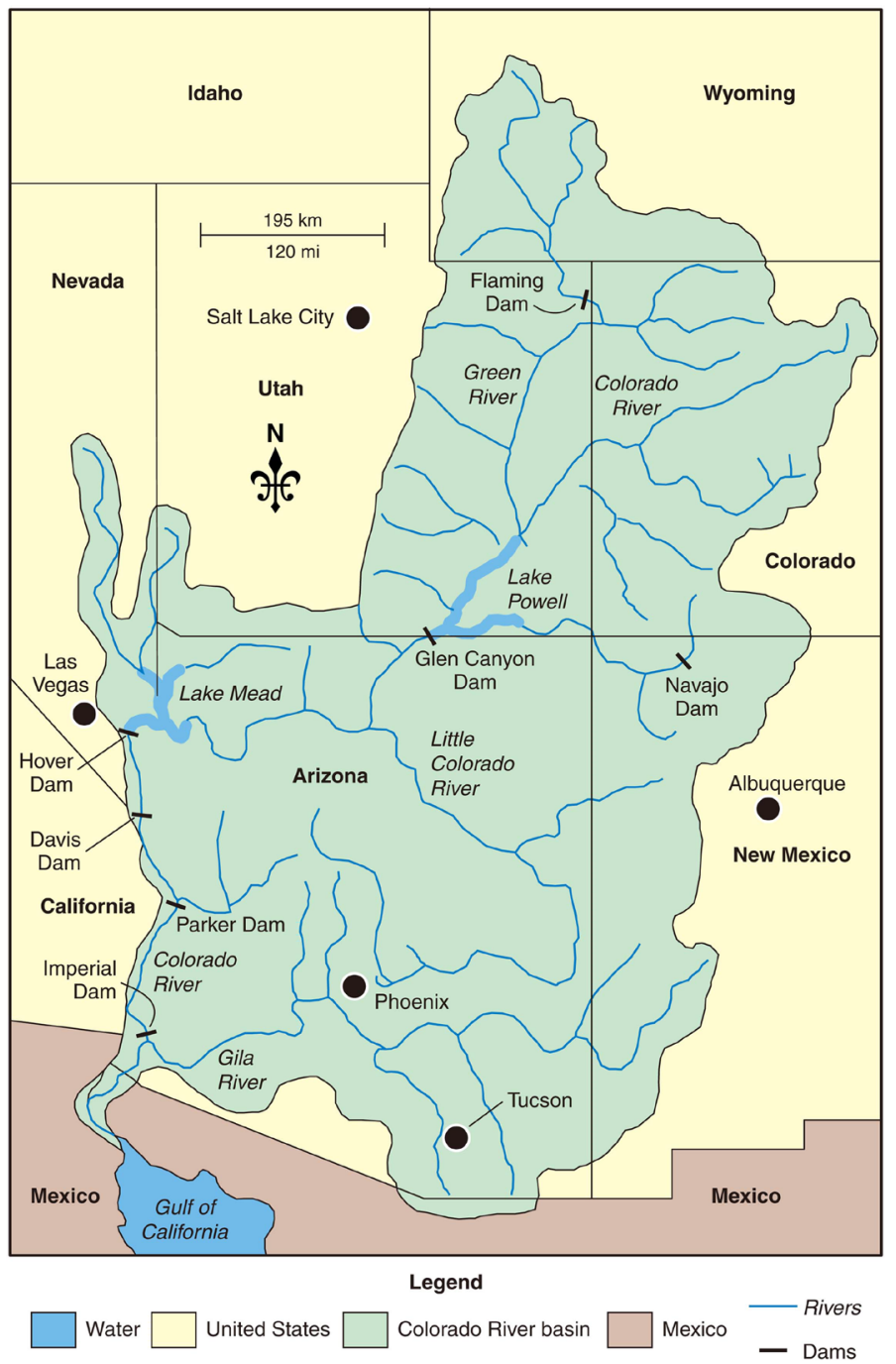

Figure 13. Colorado River which historically drains in the Gulf of California, but the river currently runs dry most years. Map by Mic Greenberg.

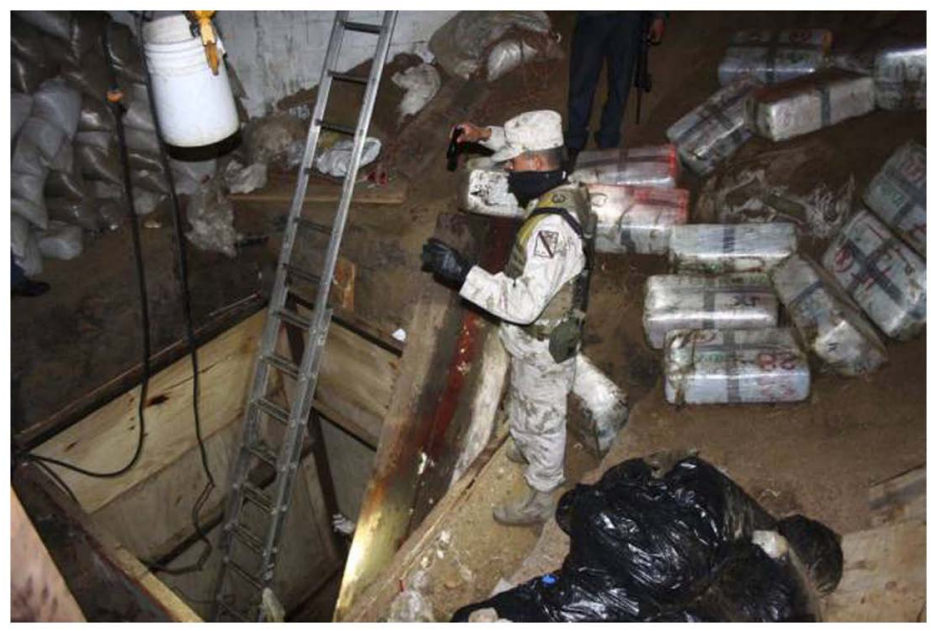

Figure 14. Soil tunnel shaft used to access a tunnel $10 \mathrm{~m}$ below the soil surface. The drug packages are lifted by a pulley system. 


\section{Summary and Conclusions}

During medieval warfare, attackers used tunnels if the fortifications were not built on solid bedrock. The tunnels in unconsolidated parent materials could provide access to undermine and collapse walls or fortifications. Soil tunnels would normally be supported by temporary wooden props and once completed the wooded props (posts and beams) were burnt using hay or straw which left the overlaying structure unsupported and the tunnels would collapse and undermine the fortification. Later, explosives were used with greater effectiveness.

A series of earthen tunnel case studies were conducted to identify the essential site conditions and modifications required to create earthen tunnels where specific site characteristics required modification to permit construction. During medieval times consolidated bedrock could not be overcome when undermining. During medieval times, the perfect site included easy to dig unconsolidated soil materials with a low water table. Later, power drills were used to create tunnels into bedrock and mitigate the limitation. The primarily site limitation that could not be overcome was flooding. The presence of a permanent highwater table is extremely limited but pumps can be used to lower the water table. The VietnamCambodia border Old Alluvium terrace soil site was in the tropics with a monsoon season, but the permanent water table was rather low during most of the year as a result of an elevated landscape position $10 \mathrm{~m}$ above the Mekong Delta and good internal soil drainage. Most sites have an aeration zone without a seasonal highwater table and have unconsolidated soil materials which can be hand dug. The goal of tunnels was to hide and protect the attackers. Soils provided the cover and were long underestimated in warfare where a superior force was defeated by an inferior force. Soils were the great equalizer as the US military found during the Vietnam War.

Earthen tunnels have been utilized in modern warfare and smuggling. In military conflicts the inferior side utilizes earthen tunnels to hide troops, supplies and equipment from the other side. The use of tunnels in most cases was in arid areas with a relatively low permanent water table. The soils and unconsolidated parent materials were often deep. However, in modern warfare shallow to bedrock sites were used when mechanical power drills were available, and the noise and vibrations could not be detected by the country or opposing force on the other side of the border or by the opposing military forces. In all cases the goal was to hide and avoid detection. In some cases, the tunnels needed to be resilient when subjected to bombing or electronic detection and need to have entrances and exits that are covered. In deeper tunnels ventilation systems were needed. One way to eliminate soil tunnels was to flood them with water or sewage. This was routinely done on the border between Gaza and Egypt. A source of water from a river, lake, sea or ocean was needed to flood the tunnels. At the Gaza strip, Mediterranean Sea water was used. The most restrictive site conditions, when creating an earthen tunnel, were flooding and a highwater table. Only flooding cannot be mitigated. 


\section{Recommendations}

Soil tunnels have a long history as defensive and offensive war strategies, invisible roads for illegal smuggling of drugs and human trafficking, and migrants seeking asylum for safety and economic opportunity. Some of the earliest tunnels were under the walls of otherwise well-fortified cities thus it is not surprising that new tunnel crossings have emerged along the physical Mexico-US border wall almost as quickly as existing ones are detected and destroyed. Tunnels are part of the arsenal of modern warfare--from Vietnam $\mathrm{Cu}$ Chi Tunnels to the Korean DMZ to the extensive tunnels of Gaza and Israel. These underground networks store weapons and supplies, shelter soldiers, are transport corridors and serve as intelligence and communication conduits.

Although peace may be elusive, the history of soil tunnels suggests a number of defensive approaches that can reduce vulnerability to illegal infiltration and increase homeland security. First, the characteristics of certain types of soil and geographies make them uniquely suited for tunnel building sites: arid climates, unconsolidated soil materials, and a deep-water table. Countries with warfare or smuggling issues along their borders, such as Israel and the United States need detailed soil and hydrology maps of their borders to identify soil types, typographies, and areas where potential soil tunnels could be constructed. In the case of Israel their entire border is susceptible as a result of the arid climate, soils and geology. The US border with Mexico has many locations that are well suited for tunnel siting and can become vulnerable wherever a new wall is created. Without a wall there is usually no need for soil tunnels.

\section{Acknowledgements}

Published with funding support from the Department of Natural Resources and Environmental Sciences, College of Agricultural, Consumer, and Environmental Science, University of Illinois, Urbana, Illinois. Co-authors want to thank Mike Tharp for fact checking and editing the manuscript.

\section{Conflicts of Interest}

The authors declare no conflicts of interest regarding the publication of this paper.

\section{References}

[1] Richemond-Barak, D. (2018) Underground Warfare. Oxford University Press, New York, 296 p. https://doi.org/10.1093/oso/9780190457242.001.0001

[2] Jones, S. (2010) Underground Warfare 1914-1918. Pence Sword Military.

[3] Olson, K.R. and Morton, L.W. (2017) Why Were the Cu Chi and Iron Triangle Soil Tunnels in Vietnam So Resilient? Open Journal of Soil Science, 7, 34-35. https://doi.org/10.4236/ojss.2017.72003

[4] Olson, K.R. and Morton, L.W. (2018) Polders, Dikes, Canal, Rice, and Aquaculture in the Mekong Delta. Journal of Soil and Water Conservation, 73, 83A-89A. https://doi.org/10.2489/jswc.73.4.83A 
[5] New York Times (2014) Tunnels Lead Right to the Heart of Israeli Fear.

[6] Joseph, A. (2015) Network of Tunnels Built by ISIS Complete with Sleeping Quarters and Electricity Supplies Discovered Underneath Recently Liberated Iraqi Towns. Daily Mail.

[7] Khoury, J.A. (2014) Egypt Right to Create Buffer Zone on Gaza Border. Haaretz.

[8] Rudoren, J. (2014) Tunnels Lead Right to the Heart of Israeli Fear. The New York Times.

[9] Pelham, N. (2012) Gaza's Tunnel Phenomenon: The Unintended Dynamics of Israel's Siege. Journal of Palestine Studies, 41. https://doi.org/10.1525/jps.2012.XLI.4.6

[10] Erlanger, S. (2007) Isolation of Gaza Chokes off Trade. The New York Times.

[11] Matza, M. (2004) In Gaza, Sewage Stains Beaches and Piles of Garbage Mount on Streets. Reuters, Philly.com.

[12] Miller, E. (2014) Hamas, Hezbollah and the Tunnels: Who's Inspiring Whom?

[13] Wikipedia (2020) Qanat Definition and Diagrams. https://en.wikipedia.org/wiki/Qanat

[14] Lichtenwald, T.G. and Perri, F.S. (2013) Terrorist Use of Smuggling Tunnels. International Journal of Criminology and Sociology, 2, 210-226.

https://doi.org/10.6000/1929-4409.2013.02.21 